\title{
Circadian Variation in Enoxacin-Induced Convulsions in Mice Coadministered with Fenbufen
}

\author{
Tohru Masukawa and Kunio Nakanishi
}

Department of Clinical Biochemistry, Faculty of Pharmaceutical Sciences, Setsunan University, Nagaotogecho 45-1 Hirakata, Osaka 573-01, Japan

Received August 2, 1996 Accepted December 9, 1996

\begin{abstract}
Susceptibility to enoxacin $(80 \mathrm{mg} / \mathrm{kg}$, p.o.)-induced convulsions was examined in mice coadministered with fenbufen $(100 \mathrm{mg} / \mathrm{kg}, \mathrm{p} . \mathrm{o}$.) over $24 \mathrm{hr}$ at 3-hr intervals (light 7:00-19:00 hr). There was a marked circadian variation in the incidence of clonic and tonic convulsions and mortality. The susceptibility to enoxacin was higher around 15:00-18:00 hr and lower around 3:00-9:00 hr; the 50\% clonic convulsive dose $\left(\mathrm{CD}_{50}\right)$ at 9:00 and 15:00 hr was 95.0 and $56.5 \mathrm{mg} / \mathrm{kg}$, respectively, its ratio being 1.64 . Under these conditions, brain enoxacin level at 15:00 hr was increased 2.43 -fold over that at 9:00 hr $30 \mathrm{~min}$ after enoxacin administration. Thus, the change of brain enoxacin may contribute to one of the causes of the above circadian variation.
\end{abstract}

Keywords: Circadian variation, Convulsion, Enoxacin

The quinolonecarboxylic acids (quinolones) have a broad antibacterial activity, but they are known to exhibit undesirable adverse reactions and drug interactions following their coadministration with other drugs (1). Quinolones are routinely coadministered with acidic nonsteroidal antiinflammatory drugs for the therapy of infectious diseases with inflammation. Recently, convulsive seizures have been reported to occur after the coadministration of some quinolones and an acidic nonsteroidal antiinflammatory drug, fenbufen, in both humans (2) and experimental animals $(3-5)$, and the combination of enoxacin and fenbufen had high potency for producing convulsion $(3-5)$.

The susceptibility to various chemical convulsants and that to audiogenic and kindled seizures were reported to vary during the light-dark cycle $(6-10)$. However, there has been no report on circadian variations in quinoloneinduced convulsion when coadministered with acidic nonsteroidal antiinflammatory drugs. Furthermore, knowledge of any diurnal rhythmicity in the susceptibility to enoxacin may lead to more effective therapy and may help elucidate the mechanisms of this convulsion. The present study was designed to examine the influence of the timing of their administration on the development of convulsion in mice.

Enoxacin and fenbufen were purchased from Sigma Chemical Co. (St. Louis, MO, USA). Male ddy mice (6- to 7-weeks-old) were obtained from Japan SLC, Inc.
(Hamamatu). The mice were housed in a room controlled at $24^{\circ} \mathrm{C}$ under a $12 \mathrm{hr} / 12 \mathrm{hr}$ dark-light cycle (light 7:00 to 19:00 hr) for two weeks before initiating the experiments and allowed free access to food and water. Enoxacin and fenbufen were each suspended in $1.0 \%$ sodium carboxymethylcellulose. Enoxacin (40, 60, 80 and $100 \mathrm{mg} / \mathrm{kg}$, p.o.) was administered orally $5 \mathrm{~min}$ after fenbufen $(100$ $\mathrm{mg} / \mathrm{kg}$, p.o.), and the animals were put singly into plastic cages $(15 \times 10 \times 13 \mathrm{~cm})$ and observed for $180 \mathrm{~min}$ for the occurrence of clonic (typical clonic movements of limbs) and tonic (flexion and extension of hindlegs) convulsions. Animal survival was recorded within $24 \mathrm{hr}$ after enoxacin. Enoxacin concentrations in the plasma and brain were determined by modifying the HPLC method of Davis et al. (11). Comparisons of the mean values were made by analysis of variance followed by Duncan's multiple range test. Analysis for circadian variation was carried out by the $\chi^{2}$ test. $\mathrm{CD}_{50}$ and $\mathrm{LD}_{50}$ were calculated by the probit method.

Since a high dose of quinolones alone was known to produce convulsions (4), we initially investigated whether enoxacin alone could produce convulsions. Mice orally administered enoxacin $(5 \mathrm{~g} / \mathrm{kg})$ exhibited no convulsions at 9:00 and 15:00 hr. So, we examined the convulsions by concomitant administration of enoxacin with fenbufen in mice.

When coadministered with fenbufen $(100 \mathrm{mg} / \mathrm{kg}$, p.o.), enoxacin ( $80 \mathrm{mg} / \mathrm{kg}$, p.o.) produced clonic convul- 


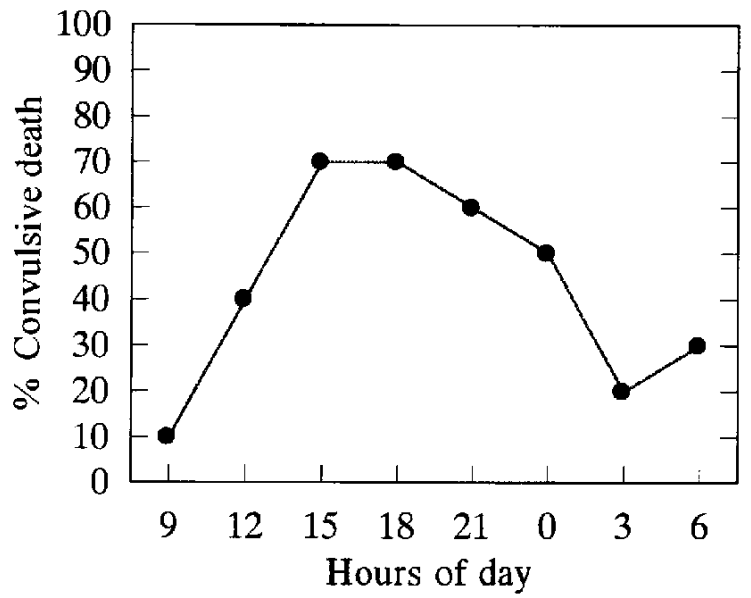

Fig. 1. Circadian variation in convulsions induced by the coadministration of enoxacin and fenbufen in mice. Enoxacin (80 $\mathrm{mg} / \mathrm{kg}$ ) was administered orally $5 \mathrm{~min}$ after fenbufen $(100 \mathrm{mg} / \mathrm{kg}$, p.o.) in mice. Ten mice were used for each time group. $P<0.01,9: 00$ hr vs 15:00 and 18:00 hr; $\mathrm{P}<0.05,9: 00 \mathrm{hr}$ vs $21: 00 \mathrm{hr}$, and 3:00 hr vs 15:00 and 18:00 hr.

sions at $15-40 \mathrm{~min}$ after administration; thereafter, tonic convulsions occurred, leading to death. Meanwhile, surviving mice showed no tonic convulsion, although they exhibited a decrease in locomotor activity. The influence of timing of coadministration of enoxacin $(80 \mathrm{mg} / \mathrm{kg}$, p.o.) and fenbufen $(100 \mathrm{mg} / \mathrm{kg}$, p.o.) on the incidence of clonic and tonic convulsion and mortality was investigated. There was a circadian variation in the incidence of convulsive death induced by coadministration of enoxacin with fenbufen in mice (Fig. $1, \chi^{2}=14.58$, df $=7$, $\mathbf{P}<0.05$ ). In this experiment, all of the mice that produced clonic convulsions proceeded to produce tonic convulsions, leading to death; therefore, all three indices were the same value at each time period. When the values at two time points were compared, a significant decrease in the incidence of convulsive death was found at 3:00 and 9:00 hr, compared to the other time points, except at
12:00, 0:00 and 6:00 hr $(\mathrm{P}<0.01,9: 00 \mathrm{hr}$ vs $15: 00$ and $18: 00 \mathrm{hr} ; \mathrm{P}<0.05,9: 00 \mathrm{hr}$ vs $21: 00 \mathrm{hr}, 3: 00 \mathrm{hr}$ vs 15:00 and 18:00 hr). No differences were observed among the other time points.

The comparison of the incidence of convulsions and mortality at two time points, 9:00 and 15:00 hr, was carried out. As shown in Table 1 , the clonic $\mathrm{CD}_{50}$ value at $9: 00 \mathrm{hr}(95.0 \mathrm{mg} / \mathrm{kg}, 78.8-154.7)$ was found to be significantly higher than that at $15: 00 \mathrm{hr}(56.5 \mathrm{mg} / \mathrm{kg}$, 47.4-64.3), its ratio at 9:00 vs $15: 00 \mathrm{hr}$ being 1.64. Similar results were also observed in the case of the $\mathrm{LD}_{50}$ value: $9: 00 \mathrm{hr}: 97.7 \mathrm{mg} / \mathrm{kg}(80.3-169.6), 15: 00 \mathrm{hr}: 56.5$ $\mathrm{mg} / \mathrm{kg}(47.4-64.3)$, the ratio at 9:00 vs $15: 00 \mathrm{hr}: 1.67$. Because all of mice that produced tonic convulsions died in this experiment, the $C_{50}$ values with regards to tonic convulsion were the same as the $\mathbf{L D}_{50}$ values. However, there was no difference in the latency up to either onset of clonic and tonic convulsion (data not shown) or death among enoxacin dosages used.

We next examined enoxacin concentrations in the plasma and brain at 30 min after its administration (Table 2). Plasma enoxacin level tended to decrease in the concomitant administration with fenbufen as compared with enoxacin alone, but such a tendency was not observed in brain enoxacin level. In the concomitant administration with fenbufen, there was no difference in plasma enoxacin level between at 9:00 hr and at 15:00 hr, whereas the brain enoxacin level at 15:00 hr was found to have increased 2.43-fold over the level at 9:00 hr. The increased enoxacin in brain may lead to the increased incidence of convulsion at 15:00 hr as compared to that at 9:00 hr, although brain fenbufen concentration was not determined and its possible involvement could not be evaluated. These findings suggest that the degree of enoxacin penetration into the brain may depend on the time of day. Therefore, the degree of penetration of enoxacin into the brain which veries with the time of day may contribute to the present circadian variation of convulsions.

As a possible mechanism for the enoxacin-induced

Table 1. Convulsions and convulsive death induced by the combination of enoxacin and fenbufen in mice

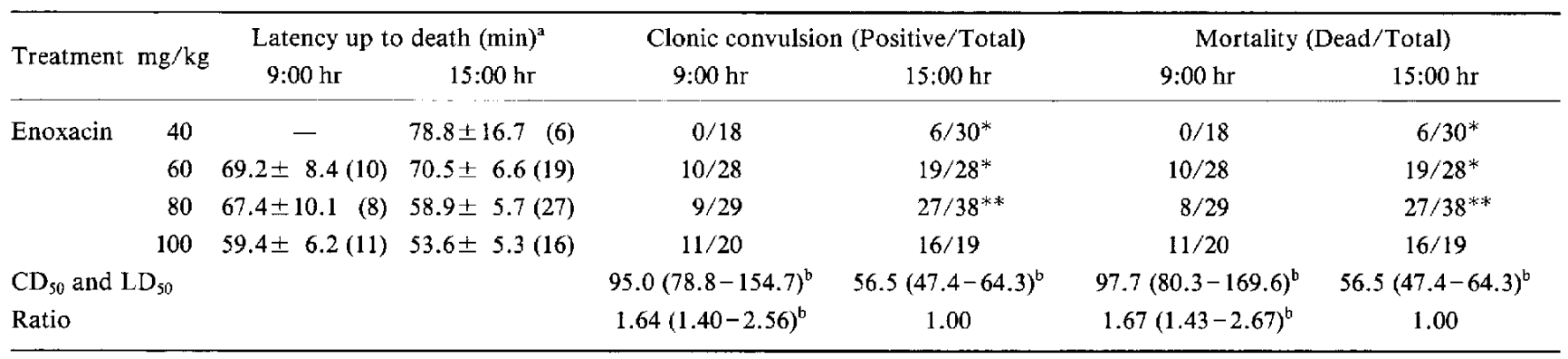

Enoxacin was administered orally $5 \mathrm{~min}$ after fenbufen $(100 \mathrm{mg} / \mathrm{kg}, \mathrm{p} . \mathrm{o}$.$) in mice. { }^{\text {a: }}$ Mean \pm S.E.M. and number of dead mice in parenthesis.

${ }^{b}: 95 \%$ confidence limit. ${ }^{*} \mathrm{P}<0.05,{ }^{* *} \mathrm{P}<0.01$ vs value at $9: 00 \mathrm{hr}$. 
Table 2. Enoxacin concentrations in plasma and brain $30 \mathrm{~min}$ after enoxacin administration in mice

\begin{tabular}{lcccc}
\hline \multirow{2}{*}{ Treatment } & \multicolumn{2}{c}{ Plasma $(\mu \mathrm{g} / \mathrm{ml})^{\mathrm{a}}$} & \multicolumn{2}{c}{${\text { Brain }(\mathrm{ng} / \mathrm{g} \text { tissue })^{\mathrm{a}}}$} \\
& $9: 00 \mathrm{hr}$ & $15: 00 \mathrm{hr}$ & $9: 00 \mathrm{hr}$ & $15: 00 \mathrm{hr}$ \\
\hline Enoxacin alone & $2.20 \pm 0.32(5)$ & $3.14 \pm 0.31(5)$ & $18.8 \pm 3.9(4)$ & $50.6 \pm 6.7(5)^{*}$ \\
Enoxacin + Fenbufen & $1.43 \pm 0.17(5)$ & $2.25 \pm 0.45(5)$ & $19.0 \pm 3.3(5)$ & $46.2 \pm 10.8(5)^{*}$ \\
\hline
\end{tabular}

Enoxacin $\left(80 \mathrm{mg} / \mathrm{kg}\right.$, p.o.) was administered $5 \mathrm{~min}$ after fenbufen $(100 \mathrm{mg} / \mathrm{kg}$, p.o. $)$ or vehicle. ${ }^{\mathrm{a}}$ : Mean \pm S.E.M. and number of mice used in parenthesis. ${ }^{*} \mathrm{P}<0.05$ vs value at $9: 00 \mathrm{hr}$.

convulsion when it is coadministered with fenbufen, the inhibitory effect of enoxacin on GABA binding to its receptors and the potentiation of fenbufen on the inhibitory effect have been reported to be associated with the expression of convulsive seizures (12). Thus, it may be possible that their suppressive potency in GABA binding to its receptors varies with the time of day and may thus be one of the underlying mechanisms involved in the present circadian variation. Thereafter, it is necessary to investigate whether their suppressive potency to GABA binding to its receptors may vary with the time of day. Gastrointestinal absorption of enoxacin tended to increase at 15:00 $\mathrm{hr}$ as compared to $9: 00 \mathrm{hr}$ and to decrease by concomitant administration of fenbufen. In this regard, further research is necessary.

From the present results, attention should be paid to the effect of time of testing for the assessment of convulsive toxicity induced by the combination use of quinolones and acidic nonsteroidal antiinflammatory drugs in experimental animals. Furthermore, the present findings are likely to provide means to avoid the development of convulsive seizures as an adverse effect in the combination use of quinolones and acidic nonsteroidal antiinflammatory drugs by changing the timing and dose in drug administration. However, further investigations are needed to judge the validity of these findings in the clinical therapy, since the aim of antimicrobial therapy should be to maintain antibacterial concentrations of the quinolones at the site of infection during the dosing interval.

In conclusion, there was a circadian variation in the incidence of enoxacin-induced convulsion in mice coadministered with fenbufen, and the susceptibility to enoxacin was higher around 15:00-18:00 hr and lower around 3:00-9:00 $\mathrm{hr}$. The change of enoxacin level in the brain may contribute to one of the causes of the present circadian variation.

\section{REFERENCES}

1 Newman M: Clinical pharmacokinetics of the newer antibacterial 4-quinolones. Clin Pharmacokinet 14, 91-121 (1988)

2 Ministry of Health and Welfare, Japan: Information on Drug Adverse Reactions, No 81, pp 1-2 (1986)

3 Hirai S, Tanaka K, Makino S and Narita H: Adverse drug interactions between pyridonecarboxylic acids and nonsteroidal antiinflammatory drugs: Convulsion after oral or intracerebral administration in mice. Yakugaku Zasshi 109, 119-126 (1989) (Abstr in English)

4 Nozaki M, Takeda N, Tanaka T, Niwa M, Inazumi K, Kaida T, Tsurumi $K$ and Fujimura $H$ : Convulsions induced by concomitant use of new quinolone antibacterial and NSAID. Jpn J Inflamm 11, 343- 348 (1991) (Abstr in English)

5 Hara Y, Ally A, Suzuki T and Tamagawa M: Central stimulating effect of the combination of the new quinolone group of antimicrobials and nonsteroidal antiinflammatory drugs in mice. Folia Pharmacol Jpn 99, 13-18 (1992) (Abstr in English)

6 Piepho RW and Friedman AH: Chronopharmacology of strychnine and allylglycine in the mouse. Clin Exp Pharmacol Physiol 4, 263-266 (1977)

7 Walker CA and Owasoyo JO: The influence of serotonin, GABA and DL-DOPA on the circadian rhythm in the toxicity of picrotoxin, pentylenetetrazol and phenobarbital in mice. Int $\mathrm{J}$ Chronobiol 2, 125-130 (1974)

8 Eidman DS, Benedito MAC and Leite JR: Daily changes in pentylenetetrazol-induced convulsions and open-field behavior in rats. Physiol Behav 47, 853-856 (1990)

9 Freeman FG: Development of kindled seizures and circadian rhythms. Behav Neural Biol 30, 231-235 (1980)

10 Halberg F, Jacobsen E, Wadsworth G and Bittner JJ: Audiogenic abnormality spectra, twenty-four hour periodicity and lighting. Science 128, 657-658 (1958)

11 Davis JD, Aarons L and Houston JB: Simultaneous assay of fluoroquinolones and theophylline in plasma by high-performance liquid chromatography. J Chromatogr 621, 105-109 (1993)

12 Tsuji A, Sato H, Kume Y, Tamai I, Okezaki E, Nagata $O$ and Kato H: Inhibitory effects of quinolone antibacterial agents on gamma-aminobutyric acid binding to receptor sites in rat brain membranes. Antimicrob Agents Chemother 32, 190- 194 (1988) 